\title{
ACUTE PARAPLEGIA BY SPINAL ANGIOLIPOMA. CASE REPORT AND LITERATURE REVIEW
}

\author{
PARAPLEGIA AGUDA POR ANGIOLIPOMA ESPINAL. RELATO DE CASO E REVISÃO DA LITERATURA \\ PARAPLEJÍA AGUDA POR ANGIOLIPOMA ESPINAL. REPORTE DE CASO Y REVISIÓN DE LA LITERATURA
}

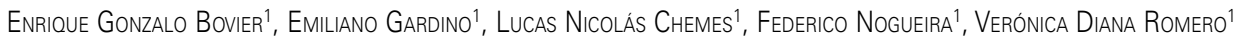

\begin{abstract}
Spinal angiolipoma is an uncommon form of benign tumor. There are 142 reported cases and only one of acute paraplegia. We describe a case of a 39 year old male with acute spinal paraplegia angiolipoma in T4-T5 with surgical resolution three weeks after the onset of the neurological syndrome. Postoperative neurologic recovery was complete. The angiolipoma consists of mature fat cells and abnormal blood vessels. There are 2 types: non-infiltrating and infiltrating. Its clinical course is slow and progressive, it can be accelerated by vascular phenomena, intratumoral abscess, and pregnancy. There is just one report of spontaneous intratumoral hemorrhage and acute paraplegia, coinciding with our case. There is no consensus as to treatment, and release and complete resection are suggested, as it is a disease with good prognosis. Angiolipoma spinal epidural is a rare form of benign tumor, and the treatment of this pathology continues to be release and resection of the tumor, with a favorable prognosis, despite the delay in surgery, as in the case reported. Intratumoral bleeding should be considered a cause of acute spinal compression syndrome, as ocurred in our patient.
\end{abstract}

Keywords: Angiolipoma; Spinal cord compression; Spinal cord neoplasms; Paraplegia.

\section{RESUMO}

O angiolipoma espinhal é um tumor benigno incomum. Há 142 casos notificados, com apenas um de paraplegia aguda. Descrevemos o caso de um paciente de 39 anos com paraplegia aguda decorrente de angiolipoma espinal em T4-T5 com resolução cirúrgica três semanas após o início da síndrome neurológica. A recuperação neurológica pós-operatória foi completa. O angiolipoma consiste em células adiposas maduras e vasos sanguíneos anormais. Existem dois tipos: os não infiltrantes e os infiltrantes. Seu curso clínico é lento e progressivo, e pode ser acelerado por fenômenos vasculares, abcessos intratumorais e gravidez. Há somente um relato de hemorragia intratumoral espontânea e paraplegia aguda, coincidindo com o nosso caso. Não há consenso quanto ao tratamento, sugerindo-se a liberação e ressecção completa por ser uma doença de bom prognóstico. O angiolipoma espinal epidural é um tumor benigno incomum e o tratamento dessa patologia continua a ser a liberação e ressecção do tumor, que apresenta prognóstico favorável, apesar da demora da cirurgia, como no caso relatado. A hemorragia intratumoral deve ser considerada como causa da síndrome de compressão espinal aguda, como ocorreu com nosso paciente.

Descritores: Angiolipoma; Compressão da medula espinal; Neoplasias da medula espinal; Paraplegia.

RESUMEN

El angiolipoma espinal es una neoplasia benigna infrecuente. Hay 142 casos reportados y uno sólo de paraplejía aguda. Describimos un caso de un paciente de 39 años de edad de sexo masculino con paraplejía aguda por angiolipoma espinal T4-T5 con resolución quirúrgica tres semanas posteriores al inicio del síndrome neurológico. A recuperación neurológica postoperatoria fue completa. El angiolipoma se compone de células adiposas maduras y vasos sanguíneos anormales. Hay 2 tipos: no infiltrantes e infiltrantes. De curso clínico lento y progresivo que puede acelerarse mediante fenómenos vasculares, absceso intratumoral y el embarazo. Hay un solo reporte de hemorragia intratumoral espontánea y paraplejía aguda, coincidiendo con nuestro caso. No existe consenso para el tratamiento, sugiriéndose la liberación y resección total por ser una patología de buen pronóstico. Angiolipoma espinal epidural es un tumor benigno infrecuente siendo el tratamiento de ésta patología la liberación y resección tumoral con un pronóstico favorable, a pesar de la demora del acto quirúrgico como en el caso reportado. El sangrado intratumoral debe considerarse como causal de síndrome de compresión espinal agudo como ocurrió con nuestro paciente.

Descriptores: Angiolipoma; Compresión de la médula espinal; Neoplasias de la médula espinal; Paraplejía.

\section{INTRODUCTION}

Angiolipoma is a benign neoplasia that consists of mature adipose tissue and abnormal vascular structures and affects middle-aged, female patients (in their 30s and 40s), usually located in the mid-thoracic region. ${ }^{1-3}$ Location in the lumbar spine is not very common. ${ }^{1,4}$ It generally follows a slow and progressive clinical course, and acute myelopathy is very rare. ${ }^{6}$ There are only 142 cases of extradural spinal angiolipoma reported to date. ${ }^{3}$ They account for between $0.14 \%$ and $1.2 \%$ of all tumors of the spinal cord and $2 \%$ to $3 \%$ of epidural spinal tumors. They can be classified into two subtypes: non-infiltrating and infiltrating. Treatment of epidural spinal angiolipomas is by total surgical removal. ${ }^{3,7}$

\section{CASE HISTORY}

Male patient, 39 years of age, admitted presenting a progressive neurological profile of the lower limbs with 12 hours of evolution, with a distal T4 sensory, motor, and autonomous level (anesthesia, areflexia, paraplegia, and bladder and bowel incontinence). Presence of comorbidities of dyslipidemia and obesity. The pre-operative scoring system of the Japanese Orthopaedic Association (JOA) was used,

1. Hospital Mario V. Larrain de Berisso, Buenos Aires, Argentina.

Study conducted at the Servicio de Ortopedia y Traumatología, Hospital Mario V. Larrain de Berisso, Buenos Aires, Argentina.

Correspondence: Calle 5 (Londres) № 4453 e/ 166 y Av. Montevideo , ciudad de Berisso, provincia de Buenos Aires, Argentina. enriquebovier@hotmail.com 
with a score of 0 points for thoracic myelopathy. (Table 1)

Radiographs were taken, showing no evidence of pathology. In computed tomography (CT) scans we observed an intrachannel extradural posterior image $38.8 \mathrm{~mm}$ long at level T4 - T5 (Figure 1). Magnetic resonance (MRI) without intravenous contrast showed a fusiform posterior epidural mass with compression of the thoracic medulla in the vertebral body segments between T4 and T5, homogeneous and isointense in the T1 weighted images, mildly hyperintense in the T2 weighted images, and hyperintense in the T2 images with fat suppression. (Figure 2)

A T4 - T5 laminectomy was performed with total resection of the tumor mass 21 days after the onset of the neurological profile, due to the amount of time required for the hospital to conduct highly complex studies. Macroscopically, the tumor was dark reddish in color, elongated, encapsulated, and approximately $4 \mathrm{~cm}$ in length.

The anatomopathological study reported non-infiltrating angiolipoma.

The patient was clinically evaluated at 3,6 , and 12 months following surgery, with gradual and complete recovery of the sensory, motor, and autonomous functions with physiokinetic therapy, with a final score of the Japanese Orthopaedic Association (JOA) system score for thoracic myelopathy of 11 points. Post-operative radiography and tomography were performed as controls. (Figure 3)

Tabla 1. Japanese Orthopaedic Association Scoring System for Thoracic Myelopathy (JOA Score). ${ }^{5}$

\begin{tabular}{|c|c|}
\hline Category & Score (Point) \\
\hline \multicolumn{2}{|l|}{ Motor function } \\
\hline \multicolumn{2}{|l|}{ Lower extremity } \\
\hline Unable to stand and walk by any means & 0 \\
\hline Unable to walk without a cane or other support on a level & 1 \\
\hline Walks independently on a level but needs support on stairs & 2 \\
\hline Capable of fast but clumsy walking & 3 \\
\hline Normal & 4 \\
\hline \multicolumn{2}{|l|}{ Sensory function } \\
\hline \multicolumn{2}{|l|}{ Lower extremity } \\
\hline Apparent sensory disturbance & 0 \\
\hline Minimal sensory disturbance & 1 \\
\hline Normal & 2 \\
\hline \multicolumn{2}{|l|}{ Trunk } \\
\hline Apparent sensory disturbance & 0 \\
\hline Minimal sensory disturbance & 1 \\
\hline Normal & 2 \\
\hline \multicolumn{2}{|l|}{ Bladder function } \\
\hline Urinary retension and/or incontinence & 0 \\
\hline $\begin{array}{l}\text { Sense of retension and/or dribbling and/or thin stream } \\
\text { and/or pollakiuria }\end{array}$ & 1 \\
\hline Urinary retardation and/ or pollakiuria & 2 \\
\hline Normal & 3 \\
\hline
\end{tabular}

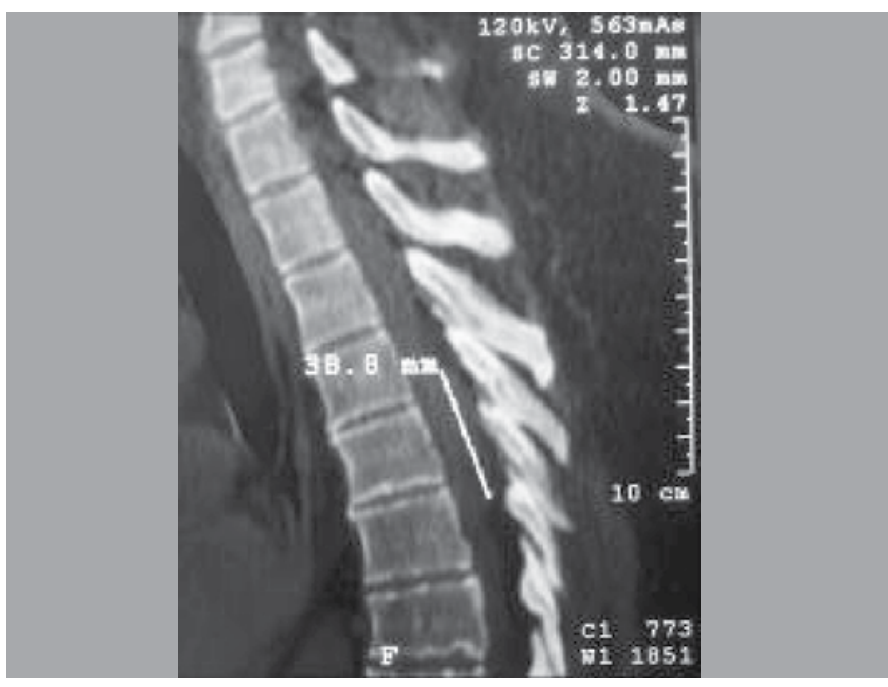

Figure 1. CT, sagittal section.
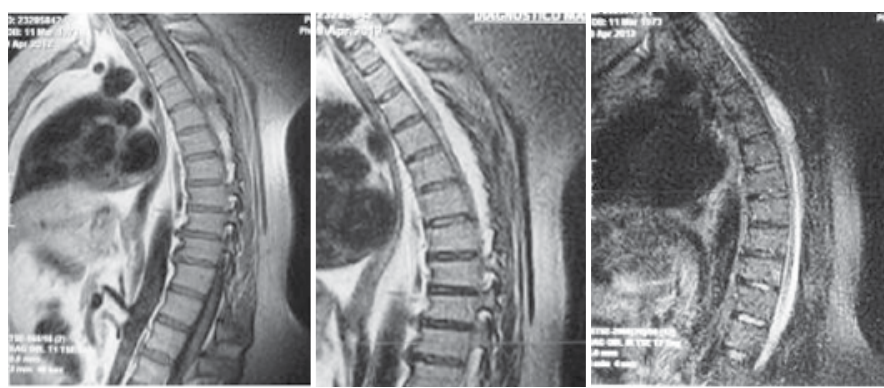

Figure 2. MRI sagittal section of the sequence $\mathrm{T} 1, \mathrm{~T} 2$, and $\mathrm{T} 2$ with fat suppression.
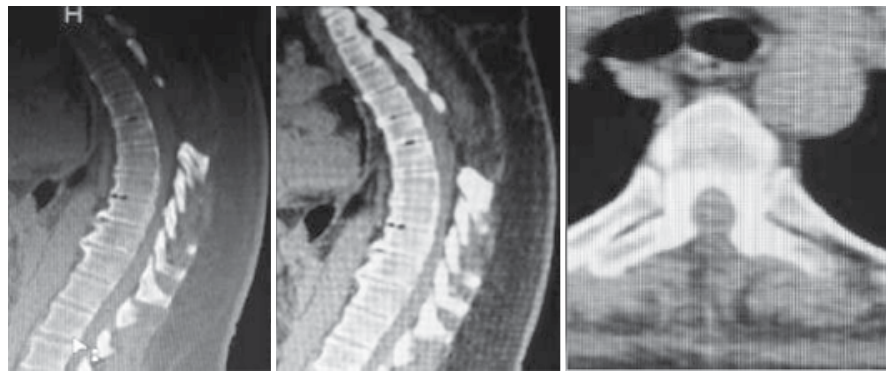

Figure 3. Post-operative CT, sagittal and axial sections

\section{DISCUSSION}

\section{Pathology}

Berenbruch et al. ${ }^{8}$ described the first case of spinal angiolipoma in 1890 in a 16 year-old with numerous cutaneous lipomas, while the first pathological report was published in 1960 by Howard and Helwig 5 in which they established angiolipoma as a defined clinical-pathological entity composed of variable proportions of mature adipose cells and capillaries, sinusoids, and abnormal venous or arterial elements. ${ }^{3,8}$ Subsequently, angiolipomas were subdivided into two categories by Lin et $a l .{ }^{9}$ non-infiltrating and infiltrating. The non-infiltrating type is encapsulated and well delimited, without invasion of the dura mater of the vertebrae. The infiltrating type is more common and usually emerges from the posterior epidural space. Infiltrating spinal angiolipomas are found in the anterior epidural space, and can invade the vertebral body. $3,4,9$

Histologically, the lesion is mostly made up of mature adipose cells and blood vessels. The fat composition is similar to that of adipose tissue, and the vascular components generally consist of capillaries, thin-walled or thick-walled sinusoids with smooth muscle, 
and occasionally, small well-developed arteries. One diagnostic characteristic is the presence of fibrin thrombi in the capillary lumen. Degenerative changes (i.e. mixoid changes, hyalinization, and fibrosis) may be present in some cases with long evolution. ${ }^{3}$

\section{Clinical presentation}

They occur mostly in women (women: men $=22: 17$ ) and most often during the 4th and 5 th decades of life. The form of presentation can be acute, subacute, or chronic and may include progressive, remittent, or recurrent radicular and paraplegic signs and symptoms. The most common initial symptoms are shoulder pain, numbness of the lower extremities, or paresthesia and weakness in the legs. But the progression can be accelerated through vascular phenomena like vascular ingurgitation, venous stasis, intratumor hemorrhage, and in rare cases, intratumor abscess. Bleeding is very rare in angiolipomas. ${ }^{3}$ Akhaddar et al ${ }^{7}$ described a case in which a spontaneous hemorrhage caused acute paraplegia similar to the clinical presentation of our patient. As with other vascular lesions, the appearance or deterioration of neurological symptoms may occur during pregnancy or with weight gain. ${ }^{1,3,7}$

Pre-operative and post-operative clinical evaluations are made using the Japanese Orthopaedic Association (JOA) scale for thoracic myelopathy. ${ }^{6}$

\section{Diagnostic evaluation}

Spinal radiography is normal, but in some cases, shows erosion of the pedicle, an increase in the diameter of the spinal canal, and trabeculation of the vertebral body affected by the infiltration of the tumors. ${ }^{6}$

Computed tomography (CT) generally shows a hypodense lesion with the density of the fat, provides information about the degree of bone involvement, and can also show variable degrees of image enhancement after the injection of contrast. ${ }^{3}$

Magnetic resonance imaging (MRI) is considered the gold standard for the diagnosis of spinal angiolipoma, which is typically isointense in $\mathrm{T} 1$ and hyperintense in T2. ${ }^{6,10,11}$ Intravenous injection of Gadolinium contrast highlights the vascularization of these tumors. ${ }^{3}$ T2 weighted images with fat suppression techniques can be very useful in distinguishing between angiolipomas and melanomas or subacute hemorrhage. .,10,11 $^{-1}$

Angiolipomas can be detected by fluorodeoxyglucose (FDG) positron emission tomography (PET). ${ }^{6}$

Spinal angiography is advantageous for differential diagnosis and the evaluation of tumor-feeding vessels. ${ }^{6}$

Differential diagnosis includes lipoma, hemangioma, malignant lymphoma, and tumors of the nerve sheath. ${ }^{6}$

\section{Treatment}

There is no clear consensus as to the best therapy for the treatment of spinal angiolipoma. The biological behaviors of non-infiltrating and infiltrating angiolipomas require different treatment focuses. The primary treatment is total surgical resection. Most non-infiltrating extradural tumors are eligible for total surgical resection through laminectomy. The posterior location of a tumor of the spinal cord facilitates resection by bilateral laminectomy. ${ }^{7}$ For total resections of non-infiltrating angiolipomas that compromise the vertebral body, an anterolateral approach and stabilization of the affected vertebrae are recommended. Although total resection of the lesion is not always easy to achieve, recurrence is rare. In cases of recurrence, extensive surgical resection followed by radiotherapy should be considered. Most patients have a good prognosis because the tumors are usually slow-growing and do not metastasize. ${ }^{8}$

\section{FINAL CONSIDERATIONS}

Spinal epidural angiolipoma is an uncommon, slow-growing, progressive benign tumor. MRI is the gold standard for diagnosis. Treatment of this pathology is by freeing and resecting of the tumor, and has a favorable prognosis, even when the surgery is delayed, as in the reported case. Intratumor bleeding should be considered as the result of a spinal compression syndrome, as occurred with our patient.

All authors declare no potential conflict of interest concerning this article.

\section{REFERENCES}

1. Akhaddar A, Albouzidi A, Elmostarchid B, Gazzaz M. Boucetta M. Sudden onset of paraplegia caused by hemorrhagic spinal epidural angiolipoma. A case report. Eur Spine J. 2008;17(Suppl 2):S296-S8.

2. Berenbruch K. Ein Fall von multiplen Angiolipomen kombiniert mit einem Angiom des Ruckenmark. Tubingen, Germany: Medical Faculty Universitat Tubingen; 1890.

3. Fujiwara H, Kaito T, Takenaka S, MakinoT, Yonenobu K. Thoracic angiolipoma: teport of two cases and review of the literature. Turk Neurosurg. 2013;23(2):271-7.

4. Gelabert-González M, García-Allut A. Spinal extradural angiolipoma: report of two cases and review of the literature. Eur Spine J. 2009:18(3):324-35.

5. Hungs M, Paré LS. Spinal angiolipoma: case report and literature review. J Spinal Cord Med. 2008;31(3):315-8
6. Meng J, Du Y, Yang HF, Hu FB, Huang YY, Li B, Zee CS. Thoracic epidural angiolipoma: a case report and review of the literature. World J Radiol. 2013;5(4):187-92.

7. Leu NH, Chen CY, Shy CG, Lu CY, Wu CS, Chen DC, et al. MR imaging of an infiltrating spinal epidural angiolipoma. AJNR Am J Neuroradiol. 2003;24(5):1008-11.

8. HowardWR, Helwig EB (1960) Angiolipoma. Arch Dermatol 82:924-931.

9. Lin JJ, Lin F. Two entities in angiolipoma. A study of 459 cases of lipoma with review of literature on infiltrating angiolipoma. Cancer. 1974;34(3):720-7.

10. Provenzale JM, Mclendon RE. Spinal angiolipomas: MR features AJNR Am J Neuroradiol. 1996;17(4):713-9.

11. Rajesh KG, Kalyan K, Srinivas D. Spinal epidural angiolipoma: a rare cause of spinal cord compression. J Neurosci Rural Pract. 2012;3(3):341-3. 